\title{
Common Core: Teaching Optimum Topic Exploration (TOTE)
}

Belinda Dunnick Karge, California State University, Fullerton, USA

Roxane Kushner Moore, California State University, Fullerton, USA

\begin{abstract}
The Common Core has become a household term and yet many educators do not understand what it means. This article explains the historical perspectives of the Common Core and gives guidance to teachers in application of Teaching Optimum Topic Exploration (TOTE) necessary for full implementation of the Common Core State Standards. An effective teacher must be a facilitator of learning, not a guardian of knowledge. The teacher should open the door for students to explore, create and think. Exceptional educators of the past - e.g. Piaget, Vygotsky, and Dewey - provide the education field with thoughts verifying the critical importance of the involvement of both educators and students in the learning process. This article gives current educators suggestions from the research of past experts to create strong lessons using the Common Core.
\end{abstract}

Keywords: Common Core; Effective Teacher; Core Lessons

\section{INTRODUCTION}

The Common Core State Standards (Council of Chief State School Officers, 2010) are a set of educational standards for kindergarten through 12th grade in English language arts and mathematics that 47 states and the District of Columbia have voluntarily chosen to adopt. The concept behind the Common Core Standard goals for student learning is that students will be prepared to enter the work force or a college program by the time they graduate from high school. The Common Core is about identifying the skills, knowledge, and habits of the mind that all learners need to be successful in society (Matsuda, 2013).

The comprehensive Common Core Standards are "field driven" and are not mandated by the Federal government. The Council of Chief State School Officers (CCSSO) purport the standards were created by state leaders, researchers, scientists, educators, school administrators, and parents. They used scholarly research, surveys of skills required of students entering college and the work force, assessment data identifying college- and careerready performance, comparisons to standards from high-performing states and nations, National Assessment of Educational Progress (NAEP) frameworks in reading and writing for English language arts, and findings from Trends in International Mathematics and Science (TIMSS) and other studies. The Common Core includes universal design concepts. Universal Design is an equitable way of learning that integrates collaborative partnerships, technology tools, and differentiated instruction in ways that provide equity for the learner (Evans, King, Metcalf \& Williams, 2010).

\section{Teaching Optimum Topic Exploration}

A guiding principle of the Common Core is the ability to comprehend and evaluate complex tasks and construct effective arguments across subjects and disciplines (EdSource Today, 2013). In order for students to have a clear understanding of the expectations in reading, writing, speaking and listening, language and mathematics in school, teachers must be creative in their thinking about how they design curriculum, plan instruction, choose resources, deliver lessons, respond to learners and use evidence to inform further teaching (Rutherford et. al., 2011). This means a teaching optimum topic exploration (TOTE) must take place (Karge \& Moore, 2013). The teacher must know their subject and the learner must be allowed to fully explore it. 
Since 1956, educators have understood the importance of Blooms' Taxonomy - moving from knowledge to comprehension to application and then analysis, synthesis and, finally, to evaluation. Yet, we are aware that many times the average teacher only implements lessons at the lower levels (knowledge and comprehension) and rarely reaches the point in a lesson where the student can actually evaluate the learning. In the 1990's, a colleague who had studied under Bloom - Lorin Anderson - worked with a group of cognitive psychologists to move the original taxonomy away from the use of nouns and use verbs (Overbaugh \& Schultz, 2013). The thought behind the newer version was that teachers would process the concepts in a way that they could easily implement into any teaching lesson or assessment. On paper, the suggestion is regal; however, in reality, the use of the new terms has not implemented nationwide as Anderson had proposed.

An effective teacher must explore the topic, understand it and be willing to shift the responsibility of learning from himself or herself to the learner (Crockett, Jukes, \& Churches, 2011). They must become the facilitator of learning, not a guardian of knowledge. Classroom teachers command the single greatest impact on student achievement (Marzano, Pickering, \& Pollock, 2001). Quality instruction is the most significant factor that influences achievement gains (Johnson, 2012).

Teaching optimum topic exploration (TOTE) will take practice and effort. The teacher needs to know the subject area or themes being presented well enough to facilitate the learning. This means time before/after school and weekends to develop higher-level questions, hypothesize what the students might inquire about, and to obtain the depth of knowledge necessary to activate knowledge. It is suggested that teachers use Anderson's verbs to plan questions to facilitate the learning. For example, determining "Can the student distinguish between the different parts?" would be a question asked in an effort for students to reach the analyzing stage of being able to appraise, compare, contrast, criticize, differentiate, discriminate, distinguish, examine, experiment and/or question (Overbaugh \& Schultz, 2013). In preparation for moving students to the point where they can create a new product or point of view, the teacher can think of ways the student can assemble, construct, design, develop, formulate or write about the topic of exploration.

The application of higher-order thinking and independent cognitive skills in the context of real life is critical (Crockett et. al., 2011). In his book, How Successful People Think, the New York Times bestselling author John C. Maxwell (2009) states that good thinkers are able to solve problems and they never lack ideas, thus they always have hope for a better future. Isn't that what we want in society? The cover of Maxwell's book (2009) says, change your thinking, change your life! If educators can allow students to explore, create, and think, the common core will be implemented with ease.

Praise should be implemented to encourage and explore. Think about how a child learns to ride a bike. For most people, it means trial and error. The adult assisting typically demonstrates how to ride, then holds the bike for the child to get on and walks alongside them until the child can peddle and take off on their own. Usually, the first solo attempt results in a fall. When this happens, the typical adult does not say, "that was a D minus, you failed"; rather, they cheer the child on, clap their hands, and say, "try again" and continue to encourage until they accomplish the task independently. In addition to praise and support, the learner should be allowed to explore the subject being taught fully. This exploration may be alone or in pairs or groups. Group work can create a successful learning environment and is fun for all involved (Karge, Phillips, \& McCabe, 2013).

\section{Sample Lesson}

So what does a lesson actually look like? The authors offer an example from the TOTE (teaching optimum topic exploration) education collection, Frogs in the Pond (Karge \& Moore, 2013). One of the first grade Common Core Standards is Reading Informational Text Standards: RI 1.3 Describe the connection between two individuals, events, ideas, or pieces of information. The content from the Frogs in the Pond (Karge \& Moore) is a simple research paragraph description of a frog:

A frog is an amphibian. Amphibians are cold blooded; they are as warm or as cold as the air or water around them. Due to their permeable skin, frogs are often semi-aquatic or inhabit humid areas, but move easily on land. The largest frog in the world lives in Africa and the smallest lives in Cuba. Most female frogs lay their eggs in the 
water and, after a few days, the egg grows into a tadpole. The tadpole grows into a frog. A frog's skin is smooth and moist. If its skin dries out, so does the inside of the frog's body, and the frog will die.

The paragraph is followed by six basic concepts (facts) such as, the best location to see a frog is by a pond, lake, marsh or swamp. It is recommended that the first time this information is used, the students should be encouraged to just listen. The second time they should listen for key words and ideas about frogs. The educator should then read both the research paragraph and the basic concepts a third time and the learner should take notes or draw a picture of what they are hearing. Next, they should read their notes to a peer, possibly using a Think-WritePair-Share strategy (Karge, 2014) and, together, they should reconstruct the text. After this, the educator should show the original text to the learners and invite them to discuss differences or similarities between the original text and their reconstruction text. Finally, there are many other exploration activities for the learners to partake. They can make a frog mask and wear it while singing three songs (provided in TOTE teachers guide). Then they can make their own pond and/or take a trip to a local pond and see if they can locate any tadpoles or frogs. The Socratic Method can be used to encourage higher-level thinking, questions, and conversations. The Socratic Method is "an open system of philosophical inquiry that allows one to interrogate for many vantage points" (retrieved from http://www.philosopher.org/Socratic Method.html; Phillips, August 21, 2013). Through discovery and inquiry, the students participate in Project-Based Learning (PBL) and work to enhance skills valued by future employers in a globalized economy (Wagner, 2008).

The initial teaching sequence of topic exploration is used by Linquanti (2012) as a teaching strategy to include English learners; additionally, it is an evidence-based strategy (judicious review) to use with persons with disabilities as indicated by Carnine, Silbert, Kameenue, \& Tarver (2010). The Socratic Method is a form of inquiry and conversation among individuals, grounded in asking and answering questions to stimulate critical thinking and to illuminate ideas. It is a common practice in working with gifted and talented youth. Teaching optimum topic explorations (TOTE) opens the door for every child to be viewed as a precious human being in need of challenging and liberating education. The daily use of a variety of teaching strategies opens the door for every child to be successful (Karge, 2014; Ravitch, 2010).

\section{CONCULSION}

Teaching is hard work and preparing for teaching optimum topic explorations will take time and effort. Educators need to have a deep understanding of the disciplinary literacy, including pedagogical content and language knowledge. Schools must create cultures that promote and support professional growth and collaboration (Rutherford et al., 2011) both among the learners and the educators. This means sustained collaboration and communication related to professional learning around key problems of practice and habits of the mind will be necessary to allow for creativity and critical thinking on the part of both the educator and the learners (Linquanti, 2012). To create and sustain coherence within a school around instructional goals and values, it is important for "indigenous leaders" to come forward. Grossman, Wineburg, \& Woolworth, 2001 coined the term indigenous leaders in reference to teachers who take responsibility not only for their own classrooms, but within the global school-staff community. Educators who share, open their classrooms for observation and invite colleagues in to brainstorm before and after school are indigenous leaders; they are lifelong learners. This collaboration is necessary for the advancement of $21^{\text {st }}$ century teaching and learning.

Both Piaget (1973) and Vygotsky (1978) provided the education field with thoughts verifying the critical importance of the involvement of both teachers and students in the learning process. Dewey $(1913,1975)$ specified that teachers and students invest more time, vigor and consideration when the topic is thoroughly covered and interesting to the learner. As educators, we can learn from these past experts and move forward through the standards within the Common Core to open the door for Teaching Optimum Topic Exploration (TOTE).

\section{AUTHOR INFORMATION}

Dr. Belinda Karge is a Professor at California State University, Fullerton. She is an expert in research-based instructional strategies. Her professional record demonstrates a consistent pattern of scholarly and creative activities including research, publications (two textbooks, five curriculum texts, four book chapters, and over 100 articles), 
and numerous grants (totaling over twenty million dollars). She has made plentiful refereed presentations to international, state, and local groups of educators and parents. Dr. Karge has received numerous awards for her teaching and service to the profession and she was honored with the Association for Childhood Education International (ACEI) award. Email: bkarge@ fullerton.edu.

Roxane Moore is a retired educator who taught in both Iowa and California during her 40 years of teaching. She obtained her Master's degree from CSU Fullerton and then began teaching there as an adjunct faculty. Her area of expertise is reading instruction. Email: roxmoore@fullerton.edu.

\section{REFERENCES}

1. Carnine, D. Silbert, J., Kameenue, E. J., \& Tarver, S. G. (2010). Direct Instruction Reading. $\left(5^{\text {th }}\right.$ Ed). Columbus, Ohio: Charles E. Merrill.

2. Council of Chief State School Officers. (2010). Common Core State Standards, National Governors Association Center for Best Practices, Washington D.C.: Council of Chief State School Officers.

3. Crockett, L., Jukes, I., \& Churches, A. (2011). Literacy Is Not Enough: $21^{\text {st }}$ Century Fluencies for the Digital Age, California: Corwin Press.

4. Dewey, J. (1913, 1975). Interest and Effort in Education. Edwardsville, IL: Southern Illinois University Press.

5. EdSource Today. (2013). Common Core Poses Big Challenge for Students Big Opportunity for Teachers retrieved from http://www.edsource.jorg/today/2013/common-core-poses-big-challenge-for-students-bigopportunity-for-teachers/37065.

6. Evans, C., King, L., Metcalf, D., \& Williams, J. (2010). Modeling, guided instruction, and application of UDL in a rural special education teacher preparation program. Rural Special Education Quarterly, 41-47.

7. Grossman, P., Wineburg, S., \& Woolworth, S. (2001). Toward a theory of teacher community. Teachers College Record, 103(6) 942-1012.

8. Johnson, J. (2012). High Quality Instruction that Promotes Learning and Achievement for African American Male, Students, Schools Moving Up, Concord, CA: WestEd.

9. Karge, B. D. (2014). Engage 11: Strategies to Promote Student Engagement in Common Core Lessons, California: The Discovery Source.

10. Karge, B. D., \& Moore, R. K. (2013). Common Core: Teaching Optimum Topic Exploration (TOTE). Clute Institute: http://cluteinstitute.com/proceedings/2013LVProceedings.html.

11. Karge, B. D., \& Moore, R. K. (2013). Teaching Optimum Topic Exploration: Frogs in the Pond. California: CM School Supply.

12. Karge, B. D., Phillips, K., \& McCabe, M. (2013). Successful strategies for groupwork in the college classroom. Clute Institute Proceedings, Maui Hawaii: Clute Institue International.

13. Linquanti, R. (2012). Fostering English Learner Success using Common Core Standards: The Opportunity We Cannot Miss, San Francisco Bay Area Common Core State Standards Summit, October 29, 2012, Concord, CA: WestEd.

14. Marzano, R., Pickering, D., \& Pollock, J. (2001). Classroom instruction that works: Research-based strategies for increasing student achievement. Alexandria, VA: ASCD.

15. Matsuda, M. (2013). Common Core: Moving From Good to Great. California: Anaheim Union High School District.

16. Maxwell, J. C. (2009). How Successful People Think. New York: Center Street Press.

17. Overbaugh, R. C., \& Schultz, L. (2013). Blooms Taxonomy. Retrieved from http://ww2.odu.edu/educ/roverbau/Bloom/blooms taxonomy.htm August 21, 2013.

18. Piaget, J. (1973). To understand is to invent: The future of education. New York: Grossman.

19. Ravitch, D. (2010). The death and life of the great American school system: How testing and choice are undermining education. New York: Basic Books.

20. Rutherford, P., Kaylor, B, Kwit, H. C., McVicker, J., Oliver, B., Stephens-Carter, S., \& West, T. (2011). Creating a culture for learning. Virginia: Just ASK publications.

21. Vygotsky, L. (1978). Mind in society: The development of higher psychological processes. Cambridge, MA: Harvard University Press.

22. Wagner, T. (2008). The Global Achievement Gap. Cambridge, MA: Harvard University Press. 